\title{
Effects of Storage Duration and Temperature of Human Plasma and Serum on Red Blood Cell Aggregation and Shape
}

\author{
Yury A. Sheremet'ev", Alexandra N. Popovicheva, Gregory Ya. Levin \\ Federal State Institution, Nizhny Novgorod Scientific Research Institute of Traumatology and Orthopedics, \\ Ministry of Health of Russia, Nizhny Novgorod, Russia \\ Email: *ya.sher@rambler.ru
}

Received January 10, 2012; revised February 26, 2012; accepted March 22, 2012

Copyright (C) 2013 Yury A. Sheremet'ev et al. This is an open access article distributed under the Creative Commons Attribution License, which permits unrestricted use, distribution, and reproduction in any medium, provided the original work is properly cited.

\begin{abstract}
Platelet-free plasma of human blood (sodium citrate and EDTA as an anticoagulant) and serum were stored at $4^{\circ} \mathrm{C}$, room temperature $\left(25^{\circ} \mathrm{C}\right)$ and at $37^{\circ} \mathrm{C}$ for 24 hours. $\mathrm{RBC}$ aggregation decreased after incubation of plasma and serum at $37^{\circ} \mathrm{C}$ for 4 hours. The $\mathrm{RBC}$ shape was changed at the same time: discocytes transformed to echinocytes. Storage of plasma and serum at $4^{\circ} \mathrm{C}$ and room temperature did not lead to significant alterations of RBC aggregation. The RBC shape did not change in influence of such plasma and serum. The most considerable decrease of RBC aggregation and change of their shapes were observed in the plasma and serum incubated at $37^{\circ} \mathrm{C}$ for 24 hours. Dilution of incubated plasma by fresh plasma led to consistent restoration of erythrocyte shape and their aggregation.
\end{abstract}

Keywords: In Vitro Time; Plasma and Serum Storage; Temperature; RBC; Aggregation; Cell Shape

\section{Introduction}

Human red blood cell (RBC) aggregation is determined by two types of biophysical and physicochemical factors: suspending phase properties and RBC properties $[1,2]$. Plasma proteins, such as fibrinogen, $\alpha_{2}$-macroglobulin, and immunoglobulins play a crucial role in the RBC aggregation [3-5]. At the same time, an open question "what other plasma factors may influence directly or through a change in cellular properties on RBC aggregation" remains.

Uyuklu et al. [6] observed that long storage of human whole blood at room temperature resulted in change of $\mathrm{RBC}$ rheologic properties. At room temperature, RBC aggregation remained stable for at least four hours. Aggregation decreased after six hours and was $50 \%$ of control after 24 hours. It was also shown that after 2 hours of rat blood at room temperature, there was a significant decrease in RBC aggregation [7]. Also, in the alteration of RBC aggregation for blood containing the anticoagulant CPDA1 stored at $4^{\circ} \mathrm{C}$, the effect of the plasma factor was slightly stronger than that of the cellular factor [8]. It was shown that the shape plays a crucial role in the aggrega-

*Corresponding author. tion and sedimentation of red cells $[9,10]$.

In the present study, we investigated the influence of human autologous plasma and serum after being stored for 24 hours at $4{ }^{\circ} \mathrm{C}$, room temperature $\left(25^{\circ} \mathrm{C}\right)$ and at $37^{\circ} \mathrm{C}$, on the $\mathrm{RBC}$ aggregation and shape.

\section{Materials and Methods}

\subsection{Blood Samples}

Venous blood was obtained from 8 healthy donors into vacuum tubes containing $\mathrm{K}_{2}$-EDTA $(5.4 \mathrm{mg} / \mathrm{ml})$ or $3.2 \%$ sodium citrate (in a ratio 9:1) as an anticoagulant. Platelet-free plasma was separated by blood centrifugation at $3000 \mathrm{~g}$ for $20 \mathrm{~min}$. Platelets and leukocytes were removed and $\mathrm{RBC}$ were washed three times with a physiological solution. To obtain serum, blood was collected into vacuum tubes do not containing anticoagulant. RBC were resuspended in plasma and serum, and the hematocrit was adjusted to $35 \pm 0.5 \%$.

\subsection{Storage of Plasma and Serum}

Plasma and serum of blood were stored at $4^{\circ} \mathrm{C}$, room temperature $\left(25^{\circ} \mathrm{C}\right)$ and at $37^{\circ} \mathrm{C}$ for 24 hours. $\mathrm{RBC}$ were kept at $4^{\circ} \mathrm{C}$ for all period of investigation (i.e., 24 hours). 
$\mathrm{RBC}$ aggregation in plasma and serum stored at $4^{\circ} \mathrm{C}$ for 24 hours was not differed from aggregation of fresh $\mathrm{RBC}$, which was determined immediately after vein puncture.

\subsection{Laboratory Tests}

\subsubsection{Red Blood Cell Aggregation}

$\mathrm{RBC}$ aggregation was investigated using a rheoscope according to the method of Schmid-Schönbein et al. [11] in our modification [12]. Our modification enables us to study of RBC and platelets aggregation. The RBC were placed between two plane-parallel plates rotating in opposite directions. In the centre of the bottom plate there was a cylindrical excavation with a depth of $90 \mu \mathrm{m}$. A chamber was formed between the contact at the top and bottom plates. The RBC suspension was placed in this chamber. The system of integration of light flow was used for registration of the aggregation. The light flow was measured by photodiode with further registration by recorder from ring of camera radius.

The RBC aggregation was registered after hydrodynamic mixing and stop (i.e., at the absence of shear stress). The assessment maximal amplitude of aggregatogram (Ma, mm).

\subsubsection{Red Blood Cell Shape}

The erythrocyte shape was studied by means of light microscopy. The erythrocytes were fixed with $1 \%$ solution glutaraldehyde.

\subsection{Statistical Analyses}

Data are presented as mean \pm standard error (SE). The results of this study were tested by using nonparametric statistics methods using the Mann-Whitney test and Wilcoxon matched pairs test.

\section{Results and Discussion}

Figure 1 shows RBC aggregation index "Ma" values in human plasma and serum. The aggregation of washed erythrocytes in autologous plasma anticoagulated with sodium citrate showed a 19\% decrease in comparison with aggregation of not washed erythrocytes.

The aggregation of washed erythrocytes in fresh autologous plasma anticoagulated with sodium citrate did not differ from erythrocyte aggregation in fresh plasma anticoagulated with EDTA. RBC aggregation in fresh autologous serum showed $23 \%$ decrease in comparison with erythrocyte aggregation in citrated plasma and plasma anticoagulated with EDTA (Figure 1). These results were in agreement with a previous study which indicated $40 \%$ decrease of $\mathrm{RBC}$ aggregation in fresh serum in comparison with $\mathrm{RBC}$ aggregation in plasma anticoagulated with EDTA [13].

Figures 2 and 3 show RBC aggregation index "Ma"

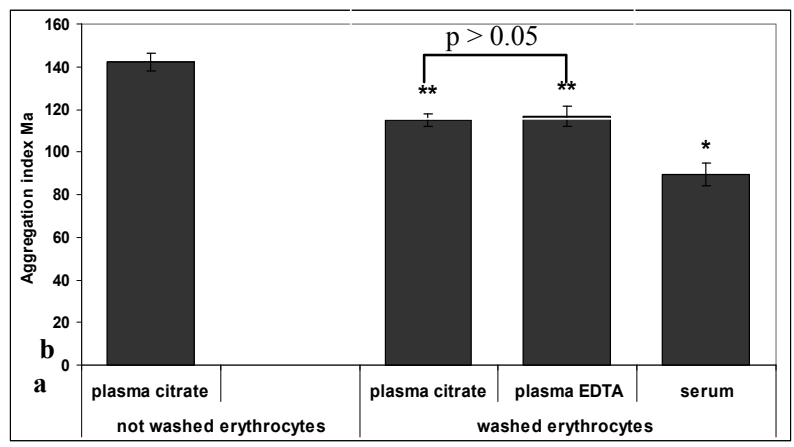

Figure 1. RBC aggregation index "Ma" in human autologous plasma and serum. Means \pm S.E. ${ }^{*} p<0.05$ vs. aggregation of washed RBC; ${ }^{* *} p<0.001$ vs. aggregation of not washed RBC.

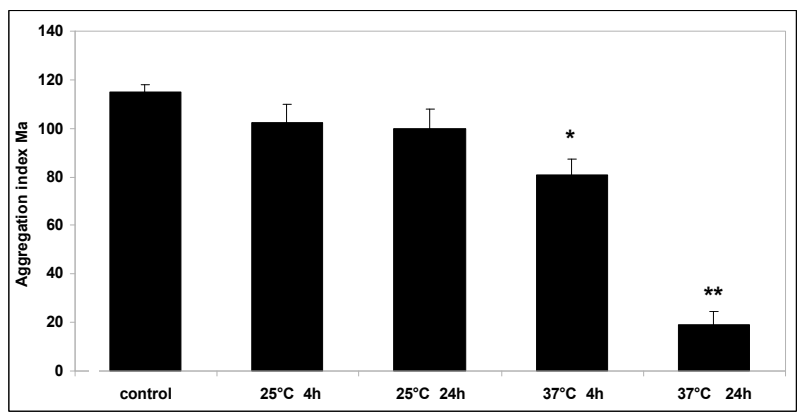

Figure 2. RBC aggregation index "Ma" for human plasma citrate stored up to 24 hours at $25^{\circ} \mathrm{C}$ and $37^{\circ} \mathrm{C}$. Means \pm S.E. Difference from control; " $p<0.05 ;{ }^{* * *} p<0.001$.

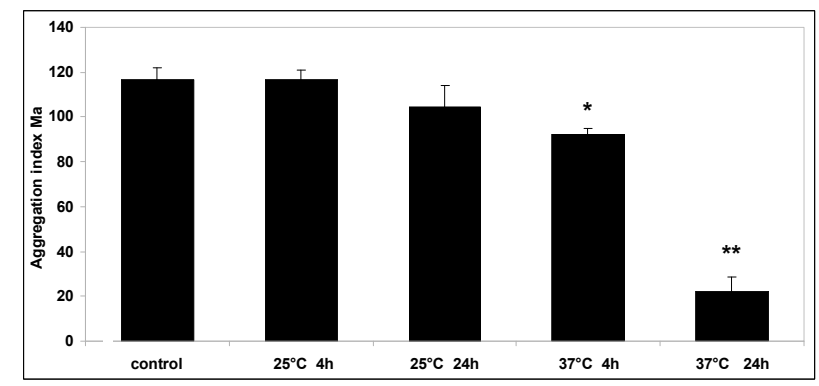

Figure 3. RBC aggregation index "Ma" for human plasma EDTA stored up to 24 hours at $25^{\circ} \mathrm{C}$ and $37^{\circ} \mathrm{C}$. Means \pm S.E. Difference from control; ${ }^{*} \mathrm{p}<0.05 ;{ }^{* * *} \mathrm{p}<0.001$.

values for human plasma citrate and EDTA stored up to 24 hours at $25^{\circ} \mathrm{C}$ and $37^{\circ} \mathrm{C}$. The addition of plasma stored at room temperature for 4 hours and 24 hours did not lead to alteration of RBC aggregation. The RBC shape did not change under these conditions.

The incubation of both plasmas even for 4 hours led to decrease of RBC aggregation (i.e., $30 \%$ and $21 \%$, respectively) in comparison with erythrocyte aggregation in fresh plasma (Figures 2 and 3). The study of RBC shape after incubated plasma for 4 hours detected the appearance of cell population with altered shape (echinocytes). 
The longer incubation of plasma (for 24 hours at $37^{\circ} \mathrm{C}$ ) resulted in most considerable decrease of RBC aggregation (more then 80\%) (Figures 2 and 3). The change of RBC shape was observed at the same time: almost all discocytes transformed to echinocytes (Figure 4).

Figure 5 shows RBC aggregation index "Ma" values for human serum were stored up to 24 hours at $25^{\circ} \mathrm{C}$ and $37^{\circ} \mathrm{C}$. The addition of serum kept at room temperature for 4 hours and 24 hours did not lead to alteration of both $\mathrm{RBC}$ aggregation and shape. The addition of serum incubated at $37^{\circ} \mathrm{C}$ for 4 hours detected a $22 \%$ decrease of erythrocyte aggregation in comparison with RBC aggregation in fresh serum. The RBC shape was also altered: discocytes transformed to echinocytes. The most considerable decrease of RBC aggregation (more then 70\%) was observed in the serum incubated at $37^{\circ} \mathrm{C}$ for 24 hours. The change of RBC shape analogous to the alteration of erythrocyte shape in incubated plasma was seen at the same time: almost all discocytes transformed to echinocytes (Figure 4).

Our results indicate that the red blood cell aggregation

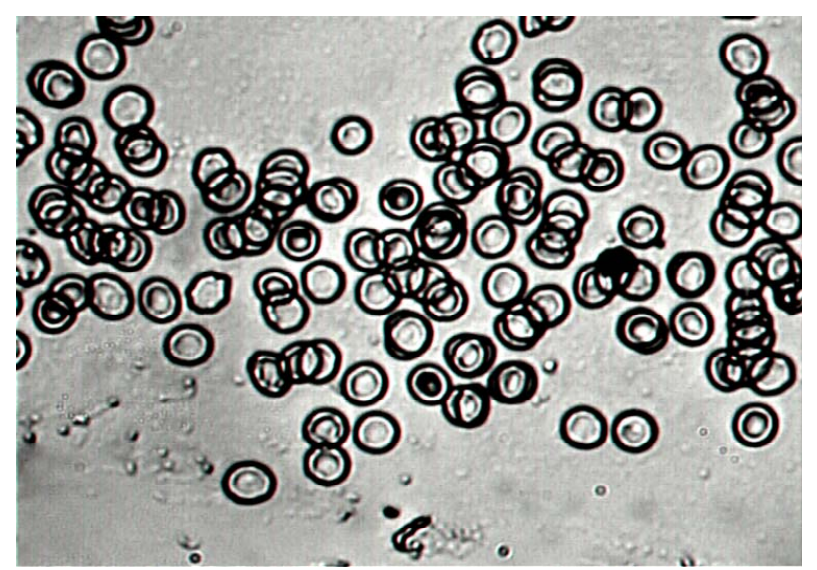

(a)

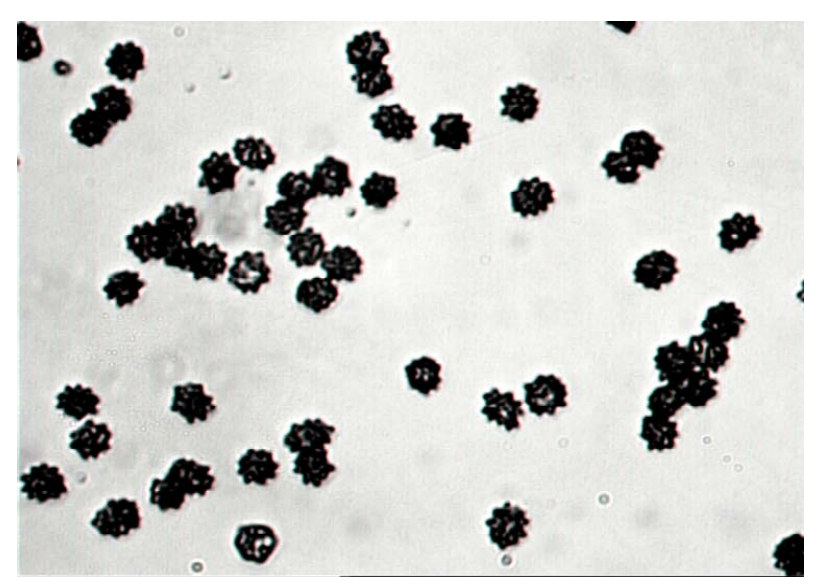

(b)

Figure 4. The RBC shape in citrated autologous plasma: (a) Control; (b) Erythrocytes in citrated plasma incubated at $37^{\circ} \mathrm{C}$ for 24 hours $(\times 1000)$. in incubated at $37^{\circ} \mathrm{C}$ plasma and serum was significantly decreased. The RBC aggregation in plasma and serum stored at room temperature did not differ from control. We found that the decrease of RBC aggregation in incubated plasma and serum was accompanied with the change shape: discocytes transformed to echinocytes.

The mechanism of alteration of RBC aggregation in incubated at $37^{\circ} \mathrm{C}$ plasma and serum of blood is unclear. It can be assumed that significant decrease of RBC aggregation connects with the appearance of active substances with an echinocytogenic effect. The experiments of dilution of incubated plasma by fresh plasma were carried out as the evidence of this supposition. The dilution of plasma in $50 \%$ restored the reduced erythrocyte aggregation (Figure 6). The dilution of incubated plasma in $80 \%$ by fresh plasma resulted in full restoration of $\mathrm{RBC}$ aggregation compared with control ( $\mathrm{p}>0.05)$.

It is known that in serum and plasma during incubation at $37^{\circ} \mathrm{C}$ for 24 hours, the high concentration of lysophosphatidic acid (LPA) is produced [14]. Scanning electronic microscopic study revealed that LPA treatment induced surface changes, and alteration of normal discocyte shape into echinocytes [15]. In our study, we associated change of RBC shape with the LPA formation.

Reinhart et al. [9,10] demonstrated that echinocytosis, induced by sodium salicylate and cytostatic mesna, led to

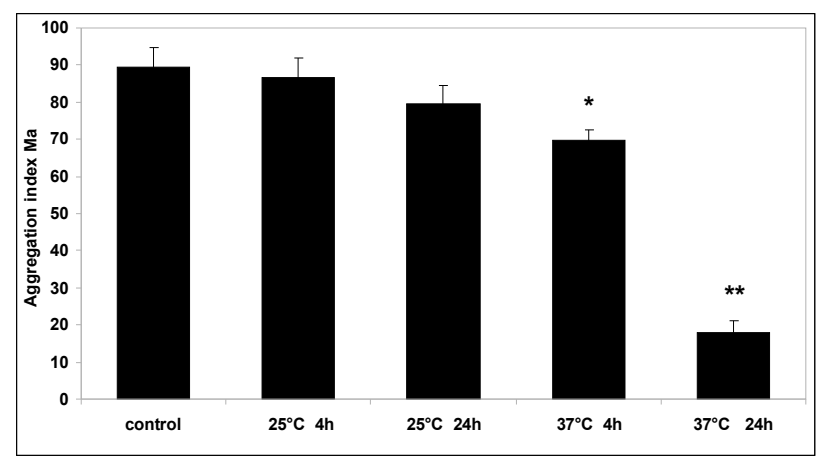

Figure 5. RBC aggregation index "Ma" for human serum stored up to 24 hours at $25^{\circ} \mathrm{C}$ and $37^{\circ} \mathrm{C}$. Means \pm S.E. Difference from control; ${ }^{*} \mathrm{p}<\mathbf{0 . 0 5} ;{ }^{* *} \mathrm{p}<\mathbf{0 . 0 0 1}$.

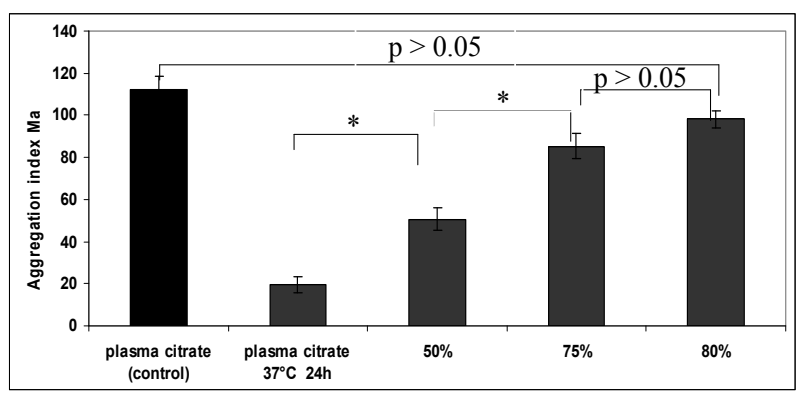

Figure 6. RBC aggregation index "Ma" for control plasma, incubated at $37^{\circ} \mathrm{C}$ for 24 hours and for plasma after dilution by normal plasma; ${ }^{*} \mathbf{p}<0.05$. 
decrease of the RBC sedimentation rate and aggregation.

We suppose that decrease of echinocytes aggregation associated with reduction of non-specific membrane binding for such blood proteins, as fibrinogen, $\alpha_{2}$-macroglobulin, and immunoglobulins. Carvalho et al. [16] demonstrated a significant decrease of the binding to fibrinogen with increase of the age of RBC. It is possible that redistribution of specific integrin-like receptors $[17,18]$ on the membrane surface plays an important role in mechanism of change of echinocyte aggregation. However, it cannot be excluded that echinocyte formation led to creation of regions with negative charge at echinocyte membranes. It is demonstrated that the discocyte-echinocyte shape transformation by lysolecithin and of ATP depletion alters the two-dimensional topography of negative charge sites RBC [19,20].

\section{REFERENCES}

[1] O. K. Baskurt and H. J. Meiselman, "Cellular Determinants of Low-Shear Blood Viscosity," Biorheology, Vol. 34, No. 3, 1977, pp. 235-247. http://dx.doi.org/10.1016/S0006-355X(97)00027-9

[2] R. W. Rampling, H. J. Meiselman, B. Neu and O. K. Baskurt, "Influence of Cell-Specific Factors on Red Blood Cell Aggregation," Biorheology, Vol. 41, No. 2, 2004, pp. 91-112.

[3] G. Barshtein, R. Ben-Ami and S. Yedgar, "Role of Red Blood Cell Flow Behavior in Hemodynamics and Hemostasis," Expert Review of Cardiovascular Therapy, Vol. 5, No. 4, 2007, pp. 743-752. http://dx.doi.org/10.1586/14779072.5.4.743

[4] T. Kirschkamp, H. Schmid-Schönbein, A. Weinberger and R. Smeets, "Effects of Fibrinogen and $\mathrm{a}_{2}$-Macroglobulin and Their Apheretic Elimination on General Blood Rheology and Rheological Characteristics of Red Blood Cell Aggregates," Therapeutic Apheresis and Dialysis, Vol. 12, No. 5, 2008, pp. 360-367. http://dx.doi.org/10.1111/j.1744-9987.2008.00610.x

[5] N. Maeda, M. Seike, S. Kume, T. Takaku and T. Shiga, "Fibrinogen-Induced Erythrocyte Aggregation: Erythrocyte-Binding Site in the Fibrinogen Molecule," Biochimica et Biophysica Acta, Vol. 904, No. 1, 1987, pp. 81-91. http://dx.doi.org/10.1016/0005-2736(87)90089-7

[6] M. M. Uyuklu, M. Cengiz, P. Ulker, T. Hever, J. Tripette, P. Connes, N. Nemeth, H. J. Meiselman and O. K. Baskurt, "Effects of Storage Duration and Temperature of Human Blood on Red Cell Deformability and Aggregation," Clinical Hemorheology and Microcirculation, Vol. 41, No. 4, 2009, pp. 269-278.

[7] N. Nemeth, O. K. Baskurt, H. J. Meiselman, F. Kiss, M. Uyuklu, T. Hever, E. Sajtos, P. Kenyeres, K. Toth, I. Furka and I. Miko, "Storage of Laboratory Animal Blood Samples Causes Hemorheological Alterations: Inter-Species Differences and the Effects of Duration and Temperature," Korea-Australia Rheology Journal, Vol. 41, No. 4, 2009, pp. 269-278.

[8] H.-J. Lim, J.-H. Nam, B.-K. Lee, J.-S. Suh and S. Shin,
"Alteration of Red Blood Cell Aggregation during Blood Storage," Korea-Australia Rheology Journal, Vol. 23, No. 2, 2011, pp. 67-70. http://dx.doi.org/10.1007/s13367-011-0009-3

[9] W. H. Reinhart, G. M. Baerlocher, T. Cerny, G. Rh. Owen, H. J. Meiselman and J. H. Beer, "Ifosfamide-Induced Stomatocytosis and Mesna-Induced Echinocytosis," European Journal of Haematology, Vol. 62, No. 4, 1999 , pp. 223-230.

http://dx.doi.org/10.1111/j.1600-0609.1999.tb01751.x

[10] W. H. Reinhart, A. Singh and P. W. Straub, "Red Blood Cell Aggregation and Sedimentation: The Role of the Cell Shape," British Journal of Haematology, Vol. 73, No. 4, 1989, pp. 551-556. http://dx.doi.org/10.1111/j.1365-2141.1989.tb00296.x

[11] H. Schmid-Schönbein, J. von Gosen, L. Heinich, H. J. Klose and E. Volger, "Counter-Rotating 'Rheoscope Chamber' for the Study of the Microrheology of Blood Cell Aggregation by Microscopic Observation and Microphotometry," Microvascular Research, Vol. 6, No. 3, 1973, pp. 366-376. http://dx.doi.org/10.1016/0026-2862(73)90086-1

[12] G. Ya. Levin, A. P. Modin, S. Yu. Kudritskiy and L. N. Sosnina, "The Device for Investigation of Platelet Aggregation," Patent 2278381, Russian Federation, 2006.

[13] S. Shin, M. S. Park, J. H. Jang, Y. H. Ku and J. S. Suh, "Measurement of Red Blood Cell Aggregation by Analysis of Light Transmission in a Pressure-Driven Slit Flow System," Korea-Australia Rheology Journal, Vol. 16, No. 2, 2004, pp. 129-134.

[14] J. A. Aoki, A. Taira, Y. Takanezawa, Y. Kishi, K. Hama, T. Kishimoto, K. Mizuno, K. Saku, R. Taguchi and H. Arai, "Serum Lysophosphatidic Acid Is Produced through Diverse Phospholipase Pathways," Journal of Biological Chemistry, Vol. 277, No. 50, 2002, pp. 48737-48744. http://dx.doi.org/10.1074/jbc.M206812200

[15] S.-M. Chung, O.-N. Bae, K.-M. Lim, J.-Y. Noh, M.-Y. Lee, Y.-S. Jung and J.-H. Chung, "Lysophosphatidic Acid Induces Thrombogenic Activity through Phosphatidylserine Exposure and Procoagulant Microvesicle Generation in Human Erythrocytes," Arteriosclerosis, Thrombosis, and Vascular Biology, Vol. 27, No. 2, 2007, pp. 414421.

http://dx.doi.org/10.1161/01.ATV.0000252898.48084.6a

[16] F. A. Carvalho, S. de Oliveira, T. Freitas, S. Goncalves and N. C. Santos, "Variations on Fibrinogen-Erythrocyte Interactions during Cell Aging," PLoS One, Vol. 6, No. 3, 2011, pp. 1-8.

http://dx.doi.org/10.1371/journal.pone.0018167

[17] D. Lominadze and W. L. Dean, "Involvement of Fibrinogen Specific Binding in Erythrocyte Aggregation," FEBS Letters, Vol. 577, No. 1-3, 2002, pp. 41-44. http://dx.doi.org/10.1016/S0014-5793(02)02575-9

[18] F. A. Carvalho, S. Connell, G. Miltenberger-Miltenyi, S. V. Pereira, A. Tavares, R. A. Ariens and N. C. Santos, "Atomic Force Microscopy-Based Molecular Recognition of a Fibrinogen Receptor on Human Erythrocytes," ACS Nano, Vol. 4, No. 8, 2010, pp. 4609-4620.

http://dx.doi.org/10.1021/nn1009648 
[19] Y. Marikovsky, C. S. Brown, R. S. Weinstein and H. H. Wortis, "Effects of Lysolecithin on the Surface Properties of Human Erythrocytes," Experimental Cell Research, Vol. 98, No. 2, 1976, pp. 313-324.

http://dx.doi.org/10.1016/0014-4827(76)90443-2

[20] Y. Marikovsky, R. S. Weinstein, E. Skutelsky and D. Danon, "Changes of Cell Shape and Surface Charge Topog- raphy in ATP-Depleted Human Red Blood Cell," Mechanisms of Ageing and Development, Vol. 29, No. 3, 1985, pp. 309-316.

http://dx.doi.org/10.1016/0047-6374(85)90070-3 